\title{
Chemical composition and antioxidant activity of dried powder \\ formulations of Agaricus blazei and Lentinus edodes
}

Andreia A.J. Carneiro ${ }^{\mathrm{a}, \mathrm{b}, \mathrm{c}}$, Isabel C.F.R. Ferreira ${ }^{\mathrm{b},{ }^{*}, \text { Montserrat Dueñas }^{\mathrm{a}} \text {, Lillian Barros }}{ }^{\mathrm{b}}$, Roberto da Silva ${ }^{c}$, Eleni Gomes ${ }^{c}$, Celestino Santos-Buelga ${ }^{\mathrm{a}, *}$

${ }^{a}$ Grupo de Investigación en Polifenoles (GIP-USAL), Facultad de Farmacia, Universidad de Salamanca, Campus Miguel de Unamuno, 37007 Salamanca, Spain

${ }^{\mathrm{b}}$ CIMO-ESA, Instituto Politécnico de Bragança, Campus de Santa Apolónia, Apartado 1172, 5301-855 Bragança, Portugal

${ }^{\mathrm{c}}$ Universidade Estadual Paulista, Campus de São José do Rio Preto, 2265, 15054-000 São José do Rio Preto, Brasil

*Authors to whom correspondence should be addressed (e-mail: iferreira@ipb.pt, telephone +351273303219, fax +351273325405; e-mail: csb@usal.es; telephone +34 923 294537; fax +34 923294515 


\begin{abstract}
Several mushroom species have been pointed out as sources of antioxidant compounds, besides their important nutritional value. Agaricus blazei and Lentinus edodes are among the most studied species all over the world, but those studies focused on their fruiting bodies instead of other presentations like powdered preparations used as supplements. In the present work the chemical composition (nutrients and bioactive compounds) and antioxidant activity (free radical scavenging activity, reducing power and lipid peroxidation inhibition) of dried powder formulations of the mentioned mushroom species (APF and LPF, respectively) were evaluated. Powder formulations of both species revealed the presence of essential nutrients such as proteins, carbohydrates and unsaturated fatty acids. Furthermore, they present low fat content $(<2 \mathrm{~g} / 100 \mathrm{~g})$ and can be used in low-caloric diets, just like the mushrooms fruiting bodies. APF showed higher antioxidant activity and higher content of tocopherols and phenolic compounds $(124 \mu \mathrm{g} / 100 \mathrm{~g}$ and $770 \mu \mathrm{g} / 100 \mathrm{~g}$, respectively) than LPF (32 $\mu \mathrm{g} / 100 \mathrm{~g}$ and $690 \mu \mathrm{g} / 100 \mathrm{~g})$. Both formulations might be used as antioxidant sources to prevent diseases related to oxidative stress.
\end{abstract}

Keywords: Mushrooms powder formulations, nutrients, bioactive compounds, antioxidant activity. 


\section{Introduction}

A balanced diet is one of the mainstays of therapy for the prevention of the oxidative stress, which if cannot be eliminated, at least can be controlled (Brown \& Waslien, 2003). The presence of reactive oxygen and nitrogen species (ROS and RNS, respectively) is the main factor that can aggravate or predispose the body to oxidative stress. These species are highly reactive, and can damage proteins, lipids, carbohydrates and DNA, being produced in normal metabolic processes of the organism. The production of ROS and RNS can be increased by external factors such as environmental pollution, X-rays, ultraviolet radiation, cigarette, alcohol, stress, consumption of saturated fats and some substances present in food and beverages (e.g. pesticide residues, chemical additives, preservatives, hormones) (Badarinath et al., 2010).

Reactive species play important roles in the organism in combating inflammation, killing bacteria or controlling the tone of smooth muscles. Nonetheless, their excess leads to oxidative stress, i.e., a change in the equilibrium state of the prooxidant/antioxidant reactions in living organisms (Alves, David, David, Bahia, \& Aguiar, 2010; Valko et al., 2007). Oxidative stress has been implicated in several human diseases and in the aging process (Sohal, 2002). Food antioxidants may help intrinsic antioxidant mechanisms to fight against oxidative stress.

Several mushroom species have been pointed out as sources of antioxidant compounds (Ferreira, Barros, \& Abreu, 2009), besides their important nutritional value (Kalač, 2009). Agaricus blazei is a basidiomycete, also known as sun mushroom. It is rich in $\beta$-glucans and other bioactive compounds, such as steroids, tocopherols and phenolic compounds, and has been used as an edible mushroom or functional food (medicinal mushroom) (Carvajal et al., 2012; Firenzuoli, Gori, \& Lombardo, 2007; Mattila et al., 2001; Reis, Barros, Martins, \& Ferreira, 2012; Reis, Martins, Barros, \& Ferreira, 2012; Tsai, Tsai, \& Mau, 2007; Yang, Lin, Mau, 2002). Lentinus edodes, known as shiitake mushroom, has received great attention due to positive health effects including antitumour and hypocholesterolemic activities (Kitzberger, Jr, Pedrosa, \& Ferreira, 
2007), related to the presence of $\beta$-glucans (Minato, Mizuno, Terai, \& Tsuchida, 1999). There are available in the literature different studies on the nutrient and phytochemical composition of Agaricus blazei and Lentinus edodes fruiting bodies (e.g., Andrade, Minhoni, \& Zied, 2008; Çaglarirmak, 2007; Carvajal et al., 2012; Cheung, Cheung, \& Ooi, 2003; Cheung \& Cheung, 2005; Choi, Lee, Chun, Lee, \& Lee, 2006; Firenzuoli et al., 2007; Kim et al., 2009; Kitzberger et al., 2007; Longvah \& Deosthale, 1998; Manzi, Gambelli, Marconi, Vivanti, \& Pizzoferrato, 1999; Mattila et al., 2001; Oliveira et al., 2007; Reis et al. 2012a and b; Soares et al., 2009; Tsai et al., 2007; Yang et al., 2002). Nevertheless, as far as we know, this is the first report on chemical composition (nutrients and bioactive compounds) and antioxidant activity (free radical scavenging activity, reducing power and lipid peroxidation inhibition) of dried powder formulations of the mentioned mushroom species.

\section{Material and methods}

\subsection{Mushroom species}

Dried powdered samples of Agaricus blazei (APF) and Lentinus edodes (LPF) were acquired in the commerce of natural products in São Jose do Rio Preto, state of São Paulo, Brazil. Agaricus blazei was purchased as a food supplement capsule, and only the inner part was analyzed.

\subsection{Standards and reagents}

Acetonitrile $99.9 \%, n$-hexane $95 \%$ and ethyl acetate $99.8 \%$ were of HPLC grade from Fisher Scientific (Lisbon, Portugal). The fatty acids methyl ester (FAME) reference standard mixture 37 (standard 47885-U) was purchased from Sigma (St. Louis, MO, USA), as also other individual fatty acid isomers, sugars (D(-)-fructose, $\mathrm{D}(-)$-mannitol, $\mathrm{D}(+)$-arabinose and $\mathrm{D}(+)$-trehalose), tocopherols ( $\alpha-, \beta-, \gamma$-, and $\delta$-isoforms), trolox (6-hydroxy-2,5,7,8-tetramethylchroman-2- 
carboxylic acid) and phenolic standards (gallic, $p$-hydroxybenzoic, $p$-coumaric, cinnamic, and vanillic acids). Racemic tocol, $50 \mathrm{mg} / \mathrm{mL}$ was purchased from Matreya (Pleasant Gap, PA, USA). 2,2-Diphenyl-1-picrylhydrazyl (DPPH) was obtained from Alfa Aesar (Ward Hill, MA, USA) and ABTS (2,2' 'azino-bis-(3-ethylbenzothiazoline-6-sulfonic acid) diammonium salt) was from Fluka (Madrid, Spain). All other chemicals and solvents were of analytical grade and purchased from different suppliers. Water was treated in a Milli-Q water purification system (TGI Pure Water Systems, USA).

\subsection{Chemical composition in nutritional compounds}

2.3.1. Nutritional value. The samples were analysed for chemical composition (moisture, proteins, fat, carbohydrates and ash) using the AOAC (1995) procedures. Proteins content $(\mathrm{N} \times$ 4.38) was estimated by the macro-Kjeldahl method; fat was determined by extracting a known weight of the sample with petroleum ether, using a Soxhlet apparatus; ash content was determined by incineration at $600 \pm 15{ }^{\circ} \mathrm{C}$. Carbohydrates were calculated by difference: Carbohydrates $=100-(\mathrm{g}$ protein $+\mathrm{g}$ fat $+\mathrm{g}$ ash $)$. Energy was calculated according to the following equation: Energy $(\mathrm{kcal})=4 \times(\mathrm{g}$ proteins $+\mathrm{g}$ carbohydrates $)+9 \times(\mathrm{g}$ fat $)$.

2.3.2. Sugars. Free sugars were determined by a High Performance Liquid Chromatography (HPLC) system consisted of a pump (Knauer, Smartline system 1000), degasser system (Smartline manager 5000) and auto-sampler (AS-2057 Jasco), coupled to a refraction index detector (RI detector Knauer Smartline 2300) as previously described (Reis et al., 2012a). Sugars identification was made by comparing the relative retention times of sample peaks with standards. Data were analyzed using Clarity 2.4 Software (DataApex). Quantification was based on the RI signal response of each standard, using the internal standard (IS, raffinose) method and 
through calibration curves obtained from commercial standards of each compound. The results were expressed in g per $100 \mathrm{~g}$ of dried powdered sample.

2.3.3. Fatty acids. Fatty acids were determined after a transesterification procedure as described previously (Reis et al., 2012a), using a gas chromatographer (DANI 1000) equipped with a split/splitless injector and a flame ionization detector (GC-FID). Fatty acids identification was made by comparing the relative retention times of FAME peaks from samples with standards. The results were recorded and processed using CSW 1.7 software (DataApex 1.7). The results were expressed in relative percentage of each fatty acid.

\subsection{Chemical composition in bioactive compounds}

2.4.1. Tocopherols. Tocopherols were determined following a procedure previously optimized (Reis et al., 2012a). Analysis was performed by HPLC (equipment described above), and a fluorescence detector (FP-2020; Jasco) programmed for excitation at $290 \mathrm{~nm}$ and emission at $330 \mathrm{~nm}$. The compounds were identified by chromatographic comparisons with authentic standards. Quantification was based on the fluorescence signal response of each standard, using the IS (tocol) method and calibration curves obtained from commercial standards of each compound. The results were expressed in $\mu \mathrm{g}$ per $100 \mathrm{~g}$ of dried powdered sample.

2.4.2. Phenolic compounds. Phenolic compounds were determined by HPLC (Hewlett-Packard 1100, Agilent Technologies) as previously described (Barros et al., 2013). Double online detection was carried out in the diode array detector (DAD), using $280 \mathrm{~nm}$ and $370 \mathrm{~nm}$ as preferred wavelengths, and in a mass spectrometer (API 3200 Qtrap, Applied Biosystems) equipped with an ESI source and a triple quadrupole-ion trap mass analyzer. The connection to the HPLC system was via the DAD cell outlet. The phenolic compounds were characterized 
according to their UV and mass spectra and retention times, and comparison with authentic standards when available. For quantitative analysis, calibration curves were prepared from different standard compounds. The results were expressed in $\mathrm{mg}$ per $100 \mathrm{~g}$ of dried powdered sample.

\subsection{Evaluation of antioxidant activity}

2.5.1. General. The sample ( $\sim \mathrm{g})$ was stirred with methanol:water $(80: 20, v / v ; 30 \mathrm{~mL})$, sonicated for $30 \mathrm{~min}$ and incubated at $-20{ }^{\circ} \mathrm{C}$ for $6 \mathrm{~h}$. Then, the extract was centrifuged at $5000 \mathrm{~g}$ for $15 \mathrm{~min}$ at $4{ }^{\circ} \mathrm{C}$. The residue was then re-extracted four times with methanol:water $(80: 20, v / v$; $30 \mathrm{~mL}$ ). The combined extracts were evaporated under reduced pressure (rotary evaporator Büchi R-210), weighted and re-dissolved in methanol at $20 \mathrm{mg} / \mathrm{mL}$ (stock solution), and stored at $4{ }^{\circ} \mathrm{C}$ for further use. Successive dilutions were made from the stock solution and submitted to different in vitro assays to evaluate the antioxidant activity of the samples.

2.5.2. Folin-Ciocalteu assay. A solution of the extract $(5 \mathrm{mg} / \mathrm{mL}, 1 \mathrm{~mL})$ was mixed with FolinCiocalteu reagent $(5 \mathrm{~mL}$, previously diluted with water $1: 10, v / v)$ and sodium carbonate $(75 \mathrm{~g} / \mathrm{L}$, $4 \mathrm{~mL}$ ). The mixture was vortex mixed for $15 \mathrm{~s}$ and allowed to stand for $30 \mathrm{~min}$ at $40{ }^{\circ} \mathrm{C}$ for colour development. Absorbance was then measured at $765 \mathrm{~nm}$ (Analytikjena spectrophotometer) (Reis et al., 2012b). Gallic acid was used to obtain the standard curve $(0.0094-0.15 \mathrm{mg} / \mathrm{mL})$, and the reduction of Folin-Ciocalteu reagent by the samples was expressed as mg of gallic acid equivalents (GAE) per g of extract.

2.5.3. Ferricyanide/Prussian blue assay. Solutions of the extracts at different concentrations (0.5 $\mathrm{mL})$ were mixed with sodium phosphate buffer $(200 \mathrm{mmol} / \mathrm{L}, \mathrm{pH} 6.6,0.5 \mathrm{~mL})$ and potassium ferricyanide $(1 \% w / v, 0.5 \mathrm{~mL})$. The mixture was incubated at $50{ }^{\circ} \mathrm{C}$ for $20 \mathrm{~min}$, and 
trichloroacetic acid $(10 \% w / v, 0.5 \mathrm{~mL})$ was added. The mixture $(0.8 \mathrm{~mL})$ was poured in a 48 well plate, as also deionised water $(0.8 \mathrm{~mL})$ and ferric chloride $(0.1 \% \mathrm{w} / \mathrm{v}, 0.16 \mathrm{~mL})$, and the absorbance was measured at $690 \mathrm{~nm}$ in an ELX800 Microplate Reader (Bio-Tek Instruments) (Reis et al., 2012b). The reducing power was obtained directly from the absorbances and the result was expressed as $\mathrm{EC}_{50}$ value (the extract concentrations providing 0.5 of absorbance), calculated from the graph of absorbance at $690 \mathrm{~nm}$ against extract concentrations. Trolox was used as positive control to check the experiment performance.

2.5.4. FRAP (Ferric reducing antioxidant power) assay. The FRAP reagent contained $10 \mathrm{mM}$ of 2,4,6-tris(2-pyridyl)-s-triazine (TPTZ) solution in $40 \mathrm{mM} \mathrm{HCl}, 20 \mathrm{mM} \mathrm{FeCl}{ }_{3} \cdot 6 \mathrm{H}_{2} \mathrm{O}$, and acetate buffer (300 mM, pH 3.6) $(1: 1: 10, v / v / v)$. The extract solutions with different concentrations (100 $\mu \mathrm{L})$ were added to the FRAP reagent $(3 \mathrm{~mL})$, and the absorbance was measured at $593 \mathrm{~nm}$ in an Agilent 8453 spectrophotometer after incubation at room temperature for 6 min, using the FRAP reagent as a blank (Benzie \& Strain, 1996). The reducing power was obtained directly from the absorbances and the result was expressed as $\mathrm{EC}_{50}$ value (the extract concentrations providing 0.5 of absorbance), calculated from the graph of absorbance at $593 \mathrm{~nm}$ against extract concentrations. Trolox was used as positive control.

2.5.5. ABTS scavenging activity assay. The ABTS ${ }^{+}$radical was produced by the oxidation of 7 mM ABTS with potassium persulphate (2.45 $\mathrm{mM}$ final concentration) in water. The mixture was allowed to stand in the dark at room temperature for 12-16 $\mathrm{h}$ before use, and then the ABTS ${ }^{+}$ solution was diluted with phosphate buffered saline (PBS) at $\mathrm{pH} 7.4$ and equilibrated at $30^{\circ} \mathrm{C}$ to give an absorbance of $0.7 \pm 0.02$ at $734 \mathrm{~nm}$. The extract solutions with different concentrations $(50 \mu \mathrm{L})$ were mixed with the $\mathrm{ABTS}^{+}$preparation $(2 \mathrm{~mL})$, vortexed for $10 \mathrm{~s}$, and the absorbance measured at $734 \mathrm{~nm}$ in an Agilent 8453 spectrophotometer (Agilent Technologies) after 4 min of 
reaction at $30^{\circ} \mathrm{C}$ ( $\mathrm{Re}$ et al., 1999). The radical scavenging activity (RSA) was calculated as a percentage of ABTS discolouration using the equation: $\% R S A=\left[\left(\mathrm{A}_{\mathrm{ABTS}}-\mathrm{A}_{\mathrm{S}}\right) / \mathrm{A}_{\mathrm{ABTS}}\right] \times 100$, where $A_{S}$ is the absorbance of the solution containing the sample, and $A_{A B T S}$ is the absorbance of the ABTS solution. The result was expressed as $\mathrm{EC}_{50}$ value (the extract concentrations providing $50 \%$ of antioxidant activity), calculated from the graph of ABTS scavenging activity percentage against extract concentrations. Trolox was used as positive control.

2.5.6. DPPH scavenging activity assay. A mixture consisting of a solution of extract at different concentrations $(30 \mu \mathrm{L})$ and methanolic solution $(270 \mu \mathrm{L})$ containing DPPH radicals $\left(6 \times 10^{-5}\right.$ $\mathrm{mol} / \mathrm{L}$ ) was deposited in a well of a $96-$ well plate. The mixture was left to stand for $30 \mathrm{~min}$ in the dark, and then the absorption was measured at $515 \mathrm{~nm}$ using the Microplate Reader mentioned above (Reis et al., 2012b). The radical scavenging activity (RSA) was calculated as a percentage of DPPH discolouration using the equation: \% RSA $=\left[\left(\mathrm{A}_{\mathrm{DPPH}}-\mathrm{A}_{\mathrm{S}}\right) / \mathrm{A}_{\mathrm{DPPH}}\right] \times 100$, where $\mathrm{A}_{\mathrm{S}}$ is the absorbance of the solution containing the sample, and $\mathrm{A}_{\mathrm{DPPH}}$ is the absorbance of the DPPH solution. The result was expressed as $\mathrm{EC}_{50}$ value (the extract concentrations providing $50 \%$ of antioxidant activity), calculated from the graph of DPPH scavenging activity percentage against extract concentrations. Trolox was used as positive control.

2.5.7. $\beta$-carotene/linoleate assay. A solution of $\beta$-carotene was prepared by dissolving $\beta$ carotene $(2 \mathrm{mg})$ in chloroform $(10 \mathrm{~mL})$. Two millilitres of this solution were pipetted into a round-bottom flask. The chloroform was removed at $40{ }^{\circ} \mathrm{C}$ under vacuum and linoleic acid (40 $\mathrm{mg})$, Tween 80 emulsifier $(400 \mathrm{mg})$, and distilled water $(100 \mathrm{~mL})$ were added to the flask with vigorous shaking. Aliquots $(4.8 \mathrm{~mL})$ of this emulsion were transferred into test tubes containing extract solutions with different concentrations $(0.2 \mathrm{~mL})$. The tubes were shaken and incubated at $50{ }^{\circ} \mathrm{C}$ in a water bath. As soon as the emulsion was added to each tube, the zero time absorbance 
was measured at $470 \mathrm{~nm}$ (Analytikjena spectrophotometer) (Reis et al., 2012b). $\beta$-Carotene bleaching inhibition was calculated using the following equation: ( $\beta$-carotene content after $2 \mathrm{~h}$ of assay/initial $\beta$-carotene content) $\times 100$. The result was expressed as $\mathrm{EC}_{50}$ value (the extract concentrations providing $50 \%$ of lipid peroxidation inhibition), calculated from the graph of $\beta$ carotene bleaching inhibition percentage against extract concentrations. Trolox was used as positive control.

\subsection{Statistical analysis}

For each sample three extracts were obtained and all the assays were carried out in triplicate. The results are expressed as mean values and standard deviation (SD). The results were analyzed using one-way analysis of variance (ANOVA) followed by Tukey's HSD test with $\alpha=0.05$. This treatment was carried out using SPSS v. 18.0 program.

\section{Results and discussion}

\subsection{Chemical composition in nutritional compounds}

The results of the macronutrients, estimated energetic value and individual sugars of the studied dried powder mushroom formulations are shown in Table 1. The contents of fat, proteins and ash were higher in APF, while LPF showed greater amounts of carbohydrates and slightly higher energetic value. The nutritional value of $L$. edodes fruiting bodies was previously reported in samples from Brazil (Andrade et al., 2008), Italy (Manzi et al., 1999), India (Longvah \& Deosthale, 1998), Portugal (Reis et al., 2012a) and Turkey (Çaglarirmak, 2007). LPF ash content was similar to the one observed in the sample from Brazil (3.3\%, dry weight) but was lower than the values described for the other samples (6.0-8.9\%). Regarding proteins, LPF showed proximate levels to the samples from Italy $(15.2 \%)$ and India $(16.0 \%$-value re-calculated using 4.38 as correction factor of nitrogen into protein, instead of 6.25 used by the authors), but lower 
content than the sample from Brazil (20.7\%) and Turkey (28.1\%). Fat content in LPF was lower than in all the mentioned samples (1.8-2.3\%). Carbohydrates of the powder formulation were higher than the content registered in fruiting bodies from India (64.4\%) and similar to the value observed in fruiting bodies from Portugal (87.1\%). LPF energetic contribution was lower than the one of the sample from India $(411 \mathrm{kcal} / 100 \mathrm{~g} \mathrm{dw})$, and similar to the result reported for the sample from Portugal (382 kcal/100 g dw). APF showed higher contents of ash and proteins, but lower contents of fat and carbohydrates than fruiting bodies of A. blazei from Taiwan: 6.8, 26.7, 2.6 and $63.8 \% \mathrm{dw}$, respectively (Tsai, Tsai, \& Mau, 2008). Overall, the studied powder formulations proved to have high content in carbohydrates and proteins, and low content in fat like mushroom fruiting bodies.

Mannitol and trehalose were the main free sugars found in both samples (Table 1). APF showed the highest total sugars concentration, mostly due to mannitol; LPF presented the highest levels of trehalose. Fructose and arabinose were found only in APF and LPF, respectively. The amounts of mannitol and trehalose in APF were higher than the values reported by Tsai et al. (2008) in A. blazei fruiting bodies from Taiwan (7.94 g/100 g and $2.98 \mathrm{~g} / 100 \mathrm{~g} \mathrm{dw}$, respectively). Kim et al. (2009) described the presence of trehalose in L. edodes from Korea, not as a free sugar but obtained after polysaccharides hydrolysis. The sugar amounts found in LPF were lower than the levels found in L. edodes fruiting bodies from Portugal (69.65 g/100 g dw; Reis et al., 2012a).

The distribution of saturated fatty acids (SFA), monounsaturated fatty acids (MUFA), and polyunsaturated fatty acids (PUFA) in the studied dried powder mushroom formulations are shown in Table 2. The main fatty acids found in both samples were linoleic, (C18:2n-6c), palmitic (C16:0), stearic (C18:0) and/or oleic (C18:1n-9) acids. PUFA were the main group of fatty acids, followed by SFA and then MUFA. The prevalence of PUFA, mainly due to the contribution of linoleic acid was also observed by Longvah \& Deosthale (1998) and Reis et al. 
(2012a) in fruiting bodies of L. edodes from India and Portugal, respectively (linoleic acid levels: $69 \%$ and $81 \%$ ).

The variability of chemical composition among samples of different origin might be related to environmental temperature, relative humidity during growth and relative amount of water produced or utilized during storage, as well as to the industrial processes to which the commercial mushrooms are submitted (Ouzouni, Petridis, Koller, \& Riganakos, 2009). For cultivated mushrooms, the type and amount of compost and fertilizer used can also have influence in the results (Park, Ikegaki, Alencar, \& Aguiar, 2003). Differences found in individual compounds can also be attributed to the diversity of extraction, derivatization or even quantification methods employed (Ribeiro, Pinho, Andrade, Baptista, \& Valentão, 2009).

\subsection{Chemical composition in bioactive compounds}

Tocopherol levels were higher in APF than in LPF, mainly due to the concentrations of $\alpha$ - and $\gamma$ tocopherols (Table 3); $\beta$ - and $\gamma$-tocopherols were only found in LPF and APF, respectively. The same tocopherols ( $\alpha$ - and $\gamma$-isoforms) were found in fruiting bodies of $A$. blazei from Taiwan (Tsai et al., 2007). Nevertheless, only $\gamma$-tocopherol was quantified in fruiting bodies of $L$. edodes from the same country (Yang et al., 2002). The profile observed in L. edodes samples from Portugal was also different $(\alpha-, \gamma$ - and $\delta$-isoforms) and the amount of total tocopherols was higher in that case $(53.56 \mu \mathrm{g} / 100 \mathrm{~g} \mathrm{dw}$; Reis et al., 2012a). These data highlight tocopherols as compounds with a high variability probably due to their easy degradation by oxidation processes. Accordingly, it would be expected a lower tocopherols content in mushroom powder formulations than in the corresponding fruiting bodies, as it was in fact observed.

Three phenolic compounds, $p$-hydroxybenzoic, $p$-coumaric and vanillic acids and a related compound (cinnamic acid) were identified in the studied powder formulations (Table 3). $p$ Hydroxybenzoic and cinnamic acids were found in both samples. However, trans-p-coumaric 
and vanillic acids were only found in APF and LPF, respectively. The presence of $p$ hydroxybenzoic and cinnamic acids in fruiting bodies of L. edodes was previously reported in samples from Finland and Portugal (Matilla et al., 2001; Reis et al., 2012b), in which protocatechuic acid, as well as caffeic acid in the sample from Finland were also detected. The phenolic compounds amount found in LPF was closer to the concentration observed in samples from Finland (1139 $\mu \mathrm{g} / 100 \mathrm{~g} \mathrm{dw}$; Matilla et al., 2001) than to samples from Portugal (52 $\mu \mathrm{g} / 100 \mathrm{~g} \mathrm{dw}$; Reis et al., 2012b). Carvajal et al. (2012) did not detect any of the phenolic compounds found in APF, but they reported the presence of gallic and syringic acids and pyrogallol. Considering that phenolic compounds are secondary metabolites, their production is influenced by the conditions associated to the mushrooms growth, which might explain the differences among different samples and origins.

\subsection{Antioxidant activity}

Table 4 shows the antioxidant activity of the extracts obtained from mushrooms powder formulations evaluated by different in vitro assays. APF showed higher antioxidant properties than LPF in all the performed assays.

Reducing power of APF measured by Folin-Ciocalteu assay was similar to the value obtained for A. blazei fruiting bodies from Brazil (29.64 mg GAE/g extract; Soares et al., 2009) and higher than the results reported for samples from Taiwan (5.80 mg GAE/g extract; Tsai et al., 2007) and other samples from Brazil (20.20 mg GAE/g extract; Carvajal et al., 2012). The value obtained for LPF was similar to the ones reported for samples from Portugal (8.84 mg GAE/g extract; Reis et al., 2012b), Hong Kong (9.40 mg GAE/g extract; Cheung et al., 2003) and Taiwan (9.11 mg GAE/g extract; Yang et al., 2002). Reducing power of APF (methanolic extract) measured by Ferricyanide/Prussian blue assay was similar to the result observed in a hot water extract of $A$. blazei from Taiwan, but higher than the reducing power obtained in the corresponding ethanolic 
extract $\left(\mathrm{EC}_{50}=2.92 \mathrm{mg} / \mathrm{mL}\right.$ and $6.97 \mathrm{mg} / \mathrm{mL}$, respectively; Tsai et al., 2007) and methanolic extract of samples from Brazil $\left(\mathrm{EC}_{50}=8.05 \mathrm{mg} / \mathrm{mL}\right.$, Soares et al., 2009). LPF gave similar results to L. edodes from Taiwan $\left(\mathrm{EC}_{50}=\sim 7 \mathrm{mg} / \mathrm{mL}\right.$, Yang et al., 2002), but lower reducing power than Portuguese samples $\left(\mathrm{EC}_{50}=2.62 \mathrm{mg} / \mathrm{mL}\right.$; Reis et al., 2012b). No previous results on antioxidant activity of these mushrooms species evaluated by the FRAP assay have been published as far as we know.

Regarding radical scavenging activity using DPPH assay, APF showed lower activity than alcoholic extracts of $A$. blazei from Brazil $\left(\mathrm{EC}_{50}=0.08 \mathrm{mg} / \mathrm{mL}\right.$ - Oliveira et al., $2007 ; \mathrm{EC}_{50}=3.00$ mg/mL- Soares et al., 2009; 0.305 mg/mL- Carvajal et al., 2012) and Taiwan $(2.15 \mathrm{mg} / \mathrm{mL}$; Tsai et al., 2007). LPF gave similar DPPH scavenging activity to L. edodes samples from Hong-Kong (29.4 mg/mL; Cheung et al., 2003), but lower than samples from Portugal $\left(\mathrm{EC}_{50}=6.43 \mathrm{mg} / \mathrm{mL}\right.$; Reis et al., 2012b). ABTS scavenging properties of fruiting bodies of A. blazei (Brazil) and $L$. edodes (Korea) were also previously reported (Choi et al., 2006; Carvajal et al., 2012), and in the first case $\left(\mathrm{EC}_{50}=0.084 \mathrm{mg} / \mathrm{mL}\right)$ was higher than the value obtained for APF. Lipid peroxidation inhibition of APF, measured by $\beta$-carotene/linoleate assay, was lower than the value reported by Carvajal et al. (2012) $\left(\mathrm{EC}_{50}=0.04 \mathrm{mg} / \mathrm{mL}\right)$ and higher than the result reported by Soares et al. (2009) $\left(\mathrm{EC}_{50}=2.43 \mathrm{mg} / \mathrm{mL}\right)$ in A. blazei from Brazil. Data obtained for LPF were better than lipid peroxidation inhibition of $L$. edodes samples from Hong Kong (45.8 mg/mL; Cheung et al., 2003) and Portugal (3.92 mg/mL; Reis et al., 2012b).

The observed antioxidant activity should be related to the phenolic compounds identified and quantified in the samples, evidenced by the high correlation factors obtained between antioxidant activity $\mathrm{EC}_{50}$ values and the concentrations of each phenolic compound ( $R^{2}$ values ranging from 0.7641 to 0.9935$)$. 
Overall, A. blazei and L. edodes are one of the most studied species all over the world but as food (fruiting bodies) and not as supplements like in this study. Powder formulations of both species revealed the presence of essential nutrients such as proteins, carbohydrates and unsaturated fatty acids. Furthermore, they present low fat content and can be used in low-caloric diets, just like the mushrooms fruiting bodies. Both formulations showed high antioxidant activity, especially in the case of APF, which was also richer in tocopherols and phenolic compounds than LPF. All in all, the studied formulations might be useful as antioxidant-rich supplements.

\section{Acknowledgements}

The authors are grateful to Capes-Carolina Foundation (Brazil) for the scholarship of doctoral sandwich (A.A.J. Carneiro), held at the Faculty of Pharmacy, University of Salamanca, Spain in partnership with the Polytechnic Institute of Bragança, Portugal. A.A.J. Carneiro is thankfull to FAPESP and CNPq (Brazil) for financial support and for the scholarship (Brazil). CIMO is grateful to strategic project PEst-OE/AGR/UI0690/2011 for financial support. L. Barros thanks to FCT, POPH-QREN and FSE for her grant (SFRH/BPD/4609/2008). The GIP-USAL is financially supported by the Consolider-Ingenio 2010 Programme (FUN-C-FOOD, CSD200700063). M. Dueñas thanks the Spanish “Ramón y Cajal” Programme for a contract.

\section{References}

Alves, C.Q., David, J.M., David, J.P., Bahia, M.V., \& Aguiar, R. (2010). Métodos para determinação de atividade antioxidante in vitro em substratos orgânicos. Química Nova, 33, $2202-2210$. 
Andrade, M.C.N., Minhoni, M.T.A., \& Zied, D.C. (2008). Caracterização bromatológica de oito linhagens de Lentinula edodes (Shiitake) cultivadas em toras de Eucalyptus grandis. Ciência e Tecnologia de Alimentos, 28, 793-797.

AOAC. (1995). Official methods of analysis. Arlington VA, USA: Association of Official Analytical Chemists (16th Ed.).

Badarinath, A.V., Rao, K.M., Chetty, C.M.S., Ramkanth, S., Rajan, T.V.S., \& Gnanaprakash, K.A. (2010). Review on in-vitro antioxidant methods: comparisons, correlations and considerations. International Journal of PharmTech Research, 2, 1276-1285.

Barros, L., Dueñas, M., Dias, M.I., Sousa, M.J., Santos-Buelga, C., \& Ferreira, I.C.F.R. (2013). Phenolic profiles of cultivated, in vitro cultured and commercial samples of Melissa officinalis L. infusions. Food Chemistry, 136, 1-8.

Benzie, I.F.F., \& Strain, J.J. (1996). The ferric reducing ability of plasma (FRAP) as a measure of "antioxidant power": the FRAP assay. Analytical Biochemistry, 239, 70-76.

Brown, A.C., \& Waslien, C.I. (2003). Stress and nutrition. Encyclopedia of Food Sciences and Nutrition. Academic Press, $2^{\text {a }}$ ed., 5628-5636.

Çağlarırmak, N. (2007). The nutrients of exotic mushrooms (Lentinula edodes and Pleurotus species) and an estimated approach to the volatile compounds. Food Chemistry, 105, 11881194.

Carvajal, A.E.S.S., Koehnlein, E.A., Soares, A.A., Eler, G.J., Nakashima, T.A., Bracht, A., \& Peralta, R.M. (2012). Bioactives of fruiting bodies and submerged culture mycelia of Agaricus brasiliensis (blazei) and their antioxidant properties. LWT - Food Science and Technology, 46, 493-499.

Cheung, L.M., \& Cheung, P.C.K. (2005). Mushroom extracts with antioxidant activity against lipid peroxidation. Food Chemistry, 89, 2005, 403-409 
Cheung, L.M., Cheung, P.C.K., \& Ooi, V.E.C. (2003). Antioxidant activity and total phenolics of edible mushroom extracts. Food Chemistry, 81, 249-255.

Choi, Y., Lee, S.M., Chun, J., Lee, H.B., \& Lee, J. (2006). Influence of heat treatment on the antioxidant activities and polyphenolic compounds of Shiitake (Lentinus edodes) mushroom. Food Chemistry, 99, 381-387.

Ferreira, I.C.F.R., Barros, L., \& Abreu, R.M.V. (2009). Antioxidants in wild mushrooms. Current Medicinal Chemistry, 16, 1543-1560.

Firenzuoli, F., Gori, L., \& Lombardo, G. (2008). The medicinal mushroom Agaricus blazei Murrill: Review of literature and pharmaco-toxicological problems. Evidence-Based Complementary and Alternative Medicine, 5, 3-15.

Kalač, P. (2009). Chemical composition and nutritional value of European species of wild growing mushrooms: a review. Food Chemistry, 113, 9-16.

Kim, M.-Y., Chung, L.-M., Lee, S.-J., Ahn, J.-K., Kim, E.-H., Im, M.-J., Kim, S.-L., Moon, H.I., Ro, H.-M., Kang, E.-Y., Seo, S.-H., \& Song, H.-K. (2009). Comparison of free amino acid, carbohydrates concentrations in Korean edible and medicinal mushrooms. Food Chemistry, $113,386-393$.

Kitzberger, C.S.G., Jr, A.S., Pedrosa, R.C., \& Ferreira, S.R.S. (2007). Antioxidant and antimicrobial activities of shiitake (Lentinula edodes) extracts obtained by organic solvents and supercritical fluids. Journal of Food Engineering, 80, 631-638.

Longvah, T., \& Deosthale, Y.G. (1998). Compositional and nutritional studies on edible wild mushroom from northeast India. Food Chemistry, 63, 331-334.

Manzi, P., Gambelli, L., Marconi, S., Vivanti, V., \& Pizzoferrato, L. (1999). Nutrients in edible mushrooms: an inter-species comparative study. Food Chemistry, 65, 4, 477-482.

Mattila, P., Könkö, K., Eurola, M., Pihlava, J.M., Astola, J., Vahteristo, L., Hietaniemi, V., Kumpulainen, J., Valtonen, M., \& Piironen, V. (2001). Contents of vitamins, mineral 
elements, and some phenolic compounds in cultivated mushrooms. Journal of Agricultural and Food Chemistry, 49, 2343-2348.

Minato, K., Mizuno, M., Terai, H., \& Tsuchida, H. (1999). Autolysis of lentinan, an antitumor polysaccharide, during storage of Lentinus edodes, shiitake mushroom. Journal of Agricultural and Food Chemistry, 47, 1530-1532.

Oliveira, O.M., Vellosa, J.C., Fernandes, A.S., Buffa-Filho, W., Hakime-Silva, R.A., Furlan, M., \& Brunetti, I.L. (2007). Antioxidant activity of Agaricus blazei. Fitoterapia, 78, 263-264.

Ouzouni, P.K., Petridis, D., Koller, W.-D., \& Riganakos, K.A. (2009). Nutritional value and metal content of wild edible mushrooms collected from West Macedonia and Epirus, Greece. Food Chemistry, 115, 1575-1580.

Park, Y.K., Ikegaki, M., Alencar, S.M., \& Aguiar, C.L. (2003). Determinação da concentração de $\beta$-glucano em cogumelo Agaricus blazei Murill por método enzimático. Ciência e Tecnologia de Alimentos, 23, 312-316.

Re, R., Pellegrini, N., Proteggente, A., Pannala, A., Yang, M., \& Rice-Evans, C. (1999). Antioxidant activity applying an improved ABTS radical cation decolorization assay. Free Radical Biology \& Medicine, 26, 1231-1237.

Reis, F.S., Barros, L., Martins, A., \& Ferreira, I.C.F.R. (2012a). Chemical composition and nutritional value of the most widely appreciated cultivated mushrooms: An inter-species comparative study. Food and Chemical Toxicology, 50, 191-197.

Reis, F.S., Martins, A., Barros, L., \& Ferreira, I.C.F.R. (2012b). Antioxidant properties and phenolic profile of the most widely appreciated cultivated mushrooms: A comparative study between in vivo and in vitro samples. Food and Chemical Toxicology, 50, 1201-1207.

Ribeiro, B., Pinho, P. G., Andrade, P.B., Baptista, P., \& Valentão, P. (2009). Fatty acid composition of wild edible mushrooms species: A comparative study. Microchemical Journal, 93, 29-35. 
Sohal, R.S. (2002). Role of oxidative stress and protein oxidation in the aging process. Free Radical Biology \& Medicine, 33, 37-44.

Soares, A.A., Souza, C.G.M., Daniel, F.M., Ferrari, G.P., Costa, S.M.G., \& Peralta, R.M. (2009). Antioxidant activity and total phenolic content of Agaricus brasiliensis (Agaricus blazei Murril) in two stages of maturity. Food Chemistry, 112, 775-781.

Tsai, S.-Y., Tsai, H.-L., \& Mau, F.-L. (2007). Antioxidant properties of Agaricus blazei, Agrocybe cylindracea, and Boletus edulis. LWT -Food Science and Technology, 40, 13921402.

Tsai, S.Y., Tsai, H.-L., \& Mau, J.-L. (2008). Non-volatile taste components of Agaricus blazei, Agrocybe cylindracea and Boletus edulis. Food Chemistry, 107, 977-983.

Valko, M., Leibfritz, D., Moncol, J., Cronin, M.T.D., Mazur, M., \& Telser, J. (2007). Free radicals and antioxidants in normal physiological functions and human disease. The International Journal of Biochemistry \& Cell Biology, 39, 44-84.

Yang, J.-H., Lin, H.-C., \& Mau, J.-L. (2002). Antioxidant properties of several commercial mushrooms. Food Chemistry, 77, 229-235. 
Table 1. Macronutrients and free sugars composition in dried powder formulations of Agaricus blazei (APF) and Lentinus edodes (LPF) (mean $\pm \mathrm{SD})$.

\begin{tabular}{lll}
\hline & APF & LPF \\
\hline Ash $(\mathrm{g} / 100 \mathrm{~g})$ & $7.47 \pm 0.04^{\mathrm{a}}$ & $4.29 \pm 0.10^{\mathrm{b}}$ \\
Proteins $(\mathrm{g} / 100)$ & $31.29 \pm 1.85^{\mathrm{a}}$ & $12.76 \pm 0.24^{\mathrm{b}}$ \\
Fat $(\mathrm{g} / 100 \mathrm{~g})$ & $1.82 \pm 0.03^{\mathrm{a}}$ & $1.01 \pm 0.10^{\mathrm{b}}$ \\
Carbohydrates $(\mathrm{g} / 100 \mathrm{~g})$ & $59.42 \pm 1.86^{\mathrm{b}}$ & $81.94 \pm 0.40^{\mathrm{a}}$ \\
Energy $(\mathrm{kcal} / 100 \mathrm{~g})$ & $379.24 \pm 0.29^{\mathrm{b}}$ & $387.89 \pm 0.26^{\mathrm{a}}$ \\
\hline Mannitol & $60.89 \pm 6.90^{\mathrm{a}}$ & $23.30 \pm 0.74^{\mathrm{b}}$ \\
Trehalose & $5.74 \pm 0.70^{\mathrm{b}}$ & $13.22 \pm 0.19^{\mathrm{a}}$ \\
Fructose & $0.27 \pm 0.02$ & nd \\
Arabinose & nd & $1.79 \pm 0.08$ \\
Total sugars $(\mathrm{g} / 100 \mathrm{~g})$ & $66.91 \pm 7.58^{\mathrm{a}}$ & $38.31 \pm 1.01^{\mathrm{b}}$ \\
\hline nd-not detected. In each row, the different letters represent significant differences between \\
samples $(p<0.05)$.
\end{tabular}


Table 2. Distribution of individual fatty acids (percentage) in dried powder formulations of Agaricus blazei (APF) and Lentinus edodes (LPF) (mean $\pm \mathrm{SD})$.

\begin{tabular}{|c|c|c|}
\hline Fatty acids & APF & LPF \\
\hline C6:0 & $0.14 \pm 0.01^{\mathrm{a}}$ & $0.05 \pm 0.01^{\mathrm{b}}$ \\
\hline $\mathrm{C} 8: 0$ & $0.27 \pm 0.04^{\mathrm{a}}$ & $0.11 \pm 0.01^{\mathrm{b}}$ \\
\hline C10:0 & $0.11 \pm 0.02^{\mathrm{a}}$ & $0.06 \pm 0.00^{\mathrm{b}}$ \\
\hline $\mathrm{C} 12: 0$ & $0.03 \pm 0.00^{\mathrm{b}}$ & $0.05 \pm 0.00^{\mathrm{a}}$ \\
\hline C13:0 & $0.01 \pm 0.00$ & nd \\
\hline $\mathrm{C} 14: 0$ & $0.29 \pm 0.01^{\mathrm{a}}$ & $0.25 \pm 0.01^{\mathrm{a}}$ \\
\hline C15:0 & $0.69 \pm 0.01^{\mathrm{b}}$ & $1.24 \pm 0.01^{\mathrm{a}}$ \\
\hline $\mathrm{C} 15: 1 \mathrm{c}$ & $0.01 \pm 0.00$ & nd \\
\hline C16:0 & $11.38 \pm 0.08^{\mathrm{a}}$ & $11.78 \pm 0.35^{\mathrm{a}}$ \\
\hline C16:1 & $0.10 \pm 0.00^{\mathrm{b}}$ & $0.17 \pm 0.00^{\mathrm{a}}$ \\
\hline $\mathrm{C} 17: 0$ & $0.69 \pm 0.01^{\mathrm{a}}$ & $0.28 \pm 0.02^{b}$ \\
\hline $\mathrm{C} 17: 1 \mathrm{c}$ & $0.01 \pm 0.00$ & nd \\
\hline C18:0 & $2.80 \pm 0.10^{\mathrm{a}}$ & $1.09 \pm 0.03^{\mathrm{b}}$ \\
\hline $\mathrm{C} 18: \ln 9 \mathrm{c}$ & $1.85 \pm 0.27^{\mathrm{b}}$ & $3.28 \pm 0.03^{\mathrm{a}}$ \\
\hline $\mathrm{C} 18: 2 \mathrm{n} 6 \mathrm{c}$ & $72.42 \pm 0.53^{b}$ & $78.59 \pm 0.34^{\mathrm{a}}$ \\
\hline C18:3n6 & nd & $0.59 \pm 0.06$ \\
\hline $\mathrm{C} 18: 3 \mathrm{n} 3$ & $0.32 \pm 0.02^{\mathrm{a}}$ & $0.24 \pm 0.14^{\mathrm{a}}$ \\
\hline C20:0 & $1.36 \pm 0.00^{\mathrm{a}}$ & $0.07 \pm 0.01^{\mathrm{b}}$ \\
\hline $\mathrm{C} 20: 1 \mathrm{c}$ & $0.01 \pm 0.00$ & nd \\
\hline $\mathrm{C} 20: 2 \mathrm{c}$ & $0.16 \pm 0.00^{\mathrm{a}}$ & $0.12 \pm 0.04^{\mathrm{a}}$ \\
\hline $\mathrm{C} 20: 3 \mathrm{n} 3+\mathrm{C} 21: 0$ & $0.55 \pm 0.03^{\mathrm{a}}$ & $0.17 \pm 0.10^{\mathrm{b}}$ \\
\hline $\mathrm{C} 20: 5 \mathrm{n} 3$ & $0.13 \pm 0.01^{\mathrm{a}}$ & $0.14 \pm 0.04^{\mathrm{a}}$ \\
\hline $\mathrm{C} 22: 0$ & $4.43 \pm 0.06^{\mathrm{a}}$ & $0.25 \pm 0.01^{\mathrm{b}}$ \\
\hline $\mathrm{C} 22: \ln 9$ & $0.04 \pm 0.00$ & nd \\
\hline $\mathrm{C} 23: 0$ & $0.51 \pm 0.02^{\mathrm{a}}$ & $0.20 \pm 0.03^{b}$ \\
\hline $\mathrm{C} 24: 0$ & $1.76 \pm 0.03^{\mathrm{a}}$ & $1.29 \pm 0.20^{b}$ \\
\hline SFA & $24.39 \pm 0.29^{\mathrm{a}}$ & $16.72 \pm 0.19^{b}$ \\
\hline MUFA & $2.03 \pm 0.26^{\mathrm{b}}$ & $3.45 \pm 0.02^{\mathrm{a}}$ \\
\hline PUFA & $73.58 \pm 0.55^{b}$ & $79.84 \pm 0.16^{\mathrm{a}}$ \\
\hline
\end{tabular}

Caproic acid (C6:0); caprylic acid (C8:0); capric acid (C10:0); lauric acid (C12:0); tridecanoic acid (C13: 0); myristic acid (C14:0); pentadecanoic acid (C15:0) cis-10-pentadecenoic acid (C15:1c); palmitic acid (C16:0); palmitoleic acid (C16:1); heptadecanoic acid (C17:0); cis-10heptadecenoic acid (C17:1c); stearic acid (C18:0); oleic acid (C18:1n9c); linoleic acid (C18:2n6c); $\gamma$-linolenic acid (C18:3n3); arachidic acid (C20:0); cis-11-eicosenoic acid (C20:1c); cis-11,14-eicosadienoic acid (C20:2c); cis-11,14,17- eicosatrienoic acid + heneicosanoic acid (C20:3n3 + C21:0); eicosapentaenoic acid (C20:5n3); behenic acid (C22:0); tricosanoic acid (C23:0); lignoceric acid (C24:0). SFA- saturated fatty acids; MUFA- monounsaturated fatty acids; PUFA- polyunsaturated fatty acids. nd- not detected. In each row, the different letters represent significant differences between samples $(p<0.05)$. 
Table 3. Tocopherols and phenolic compounds composition in dried powder formulations of Agaricus blazei (APF) and Lentinus edodes (LPF) (mean $\pm \mathrm{SD})$.

\begin{tabular}{lll}
\hline & APF & LPF \\
\hline$\alpha$-Tocopherol & $77.79 \pm 18.51^{\mathrm{a}}$ & $1.02 \pm 0.06^{\mathrm{b}}$ \\
$\beta$-Tocopherol & nd & $31.31 \pm 0.37$ \\
$\gamma$-Tocopherol & $46.47 \pm 12.79$ & $\mathrm{nd}$ \\
Total tocopherols $(\mu \mathrm{g} / 100 \mathrm{~g})$ & $124.25 \pm 31.30^{\mathrm{a}}$ & $32.33 \pm 0.43^{\mathrm{b}}$ \\
\hline$p$-Hydroxybenzoic acid & $0.64 \pm 0.09^{\mathrm{a}}$ & $0.42 \pm 0.06^{\mathrm{b}}$ \\
trans- $p$-Coumaric acid & $0.08 \pm 0.02$ & $\mathrm{nd}$ \\
Vanillic acid & $\mathrm{nd}$ & $0.08 \pm 0.01$ \\
Cinnamic acid & $0.05 \pm 0.01^{\mathrm{b}}$ & $0.20 \pm 0.01^{\mathrm{a}}$ \\
Total phenolic and related compounds $(\mathrm{mg} / 100 \mathrm{~g})$ & $0.77 \pm 0.12^{\mathrm{a}}$ & $0.69 \pm 0.08^{\mathrm{b}}$ \\
\hline
\end{tabular}

nd-not detected. In each row, different letters represent significant differences between species ( $p$ $<0.05)$. 
Table 4. Antioxidant activity of the extracts obtained from dried powder formulations of Agaricus blazei (APF) and Lentinus edodes (LPF) (mean \pm

$\mathrm{SD})$.

\begin{tabular}{llll}
\hline Antioxidant properties & Assay & APF & LPF \\
\hline \multirow{2}{*}{ Reducing power } & Folin-Ciocalteu $(\mathrm{mg} \mathrm{GAE} / \mathrm{g}$ extract $)$ & $31.98 \pm 5.13^{\mathrm{a}}$ & $8.10 \pm 0.42^{\mathrm{b}}$ \\
& Ferricyanide/Prussian blue $\left(\mathrm{EC}_{50}, \mathrm{mg} / \mathrm{mL}\right)$ & $2.23 \pm 0.12^{\mathrm{b}}$ & $7.54 \pm 0.46^{\mathrm{a}}$ \\
& FRAP $\left(\mathrm{EC}_{50}, \mathrm{mg} / \mathrm{mL}\right)$ & $11.15 \pm 1.14^{\mathrm{b}}$ & $64.79 \pm 2.62^{\mathrm{a}}$ \\
\hline \multirow{2}{*}{ Radical Scavenging activity } & ABTS $\left(\mathrm{EC}_{50}, \mathrm{mg} / \mathrm{mL}\right)$ & $5.02 \pm 0.97^{\mathrm{b}}$ & $24.84 \pm 4.91^{\mathrm{a}}$ \\
& DPPH $\left(\mathrm{EC}_{50} ; \mathrm{mg} / \mathrm{mL}\right)$ & $6.77 \pm 0.43^{\mathrm{b}}$ & $26.32 \pm 2.80^{\mathrm{a}}$ \\
\hline Lipid peroxidation inhibition & $\beta$-carotene bleaching inhibition $\left(\mathrm{EC}_{50} ; \mathrm{mg} / \mathrm{mL}\right)$ & $0.30 \pm 0.03^{\mathrm{b}}$ & $0.64 \pm 0.15^{\mathrm{a}}$
\end{tabular}

GAE- gallic acid equivalents. For Folin-Ciocalteu, the higher values mean higher reducing power. For the other methods, the results are presented in $\mathrm{EC}_{50}$ values, meaning that higher values correspond to lower reducing power, radical scavenging activity or lipid peroxidation inhibition. $\mathrm{EC}_{50}$ is the concentration of the extract that corresponds to $50 \%$ of antioxidant activity for the ABTS, DPPH and $\beta$-carotene bleaching inhibition assays, or 0.5 of absorbance for the FRAP and Ferricyanide/Prussian blue assays. In each row, the different letters represent significant differences between samples $(p<0.05)$ 